\title{
GENETICS IN ENDOCRINOLOGY \\ Genetic etiologies of central precocious puberty and the role of imprinted genes
}

\author{
Stephanie A Roberts ${ }^{1,2,3}$ and Ursula B Kaiser ${ }^{2,3}$ \\ 'Division of Endocrinology, Boston Children's Hospital, Boston, Massachusetts, USA, ²Division of Endocrinology, \\ Diabetes and Hypertension, Brigham and Women's Hospital, Boston, Massachusetts, USA, and ${ }^{3}$ Harvard Medical \\ School, Boston, Massachusetts, USA
}

Correspondence should be addressed to U B Kaiser

Email

ukaiser@bwh.harvard.edu

\begin{abstract}
Pubertal timing is regulated by the complex interplay of genetic, environmental, nutritional and epigenetic factors. Criteria for determining normal pubertal timing, and thus the definition of precocious puberty, have evolved based on published population studies. The significance of the genetic influence on pubertal timing is supported by familial pubertal timing and twin studies. In contrast to the many monogenic causes associated with hypogonadotropic hypogonadism, only four monogenic causes of central precocious puberty (CPP) have been described. Loss-of-function mutations in Makorin Ring Finger Protein 3 (MKRN3), a maternally imprinted gene on chromosome 15 within the Prader-Willi syndrome locus, are the most common identified genetic cause of CPP. More recently, several mutations in a second maternally imprinted gene, Delta-like noncanonical Notch ligand 1 (DLK1), have also been associated with CPP. Polymorphisms in both genes have also been associated with the age of menarche in genome-wide association studies. Mutations in the genes encoding kisspeptin (KISS1) and its receptor (KISS1R), potent activators of GnRH secretion, have also been described in association with CPP, but remain rare monogenic causes. CPP has both short- and long-term health implications for children, highlighting the importance of understanding the mechanisms contributing to early puberty. Additionally, given the role of mutations in the imprinted genes MKRN3 and DLK1 in pubertal timing, other imprinted candidate genes should be considered for a role in puberty initiation.
\end{abstract}

\section{Invited Author's profile}

Dr Roberts is a pediatric endocrinologist at Boston Children's Hospital and an Instructor of Pediatrics at Harvard Medical School. She is currently a research fellow in Dr Ursula Kaiser's laboratory in the Division of Endocrinology, Diabetes and Hypertension at Brigham and Women's Hospital. As a physician-scientist, Dr Roberts investigates observations from her clinical practice to research at the molecular level how genetic variants, sex-based differences and hormone exposure affect the neurobiology of puberty and impact child health, with the goal of then translating these

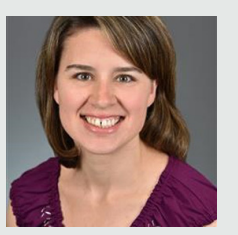
basic science discoveries back to the bedside to improve diagnosis and management of pubertal and reproductive disorders. 


\section{Introduction}

Puberty is the remarkable period during which the body develops secondary sexual characteristics and becomes capable of reproduction. The mechanisms by which pubertal onset begins remains one of science's great mysteries.

\section{Physiology of puberty}

The hallmark of pubertal onset is reactivation of the hypothalamic-pituitary-gonadal (HPG) axis, which is initially active during the fetal and neonatal periods but then undergoes a period of quiescence in childhood (1). The axis is subsequently reactivated at the onset of puberty with the reemergence of pulsatile hypothalamic gonadotropin-releasing hormone (GnRH) release, likely due to increases in activators such as kisspeptin, the most potent known stimulator of GnRH secretion, and decreases in inhibitors of the axis $(1,2)$. Kisspeptin signals directly to GnRH neurons to control pulsatile GnRH release which leads to release of luteinizing hormone (LH) and follicle-stimulating hormone (FSH) from the pituitary, with downstream activation of sex steroid production - testosterone from the testes and estrogen and progesterone from the ovaries - and stimulation of gametogenesis (Fig. 1) (1, 2).

In girls, activation of the HPG axis leads to the onset of breast development, weight gain, widening of the pelvic bones, increased fat distribution in the hips, thighs and buttocks, and menstruation, the latter of which typically occurs 18 months to 2 years after the onset of breast development $(3,4)$. In boys, puberty results initially in testicular enlargement to a size greater than or equal to 4 $\mathrm{mL}$, followed by phallic lengthening and widening, voice deepening, broadening of the chest and shoulders, the appearance of facial and male-pattern distribution hair, and ability to achieve an erection and ejaculation $(3,5)$. In both genders, the pubertal growth spurt is followed by fusion of the epiphyses. A standardized approach to characterizing the development of secondary sexual characteristics was established by Tanner in the 1960s to describe pubic hair development in both sexes as well as breast development in girls and genital development in boys $(4,5)$. Tanner stage $I$ in all scales refers to the prepubertal state, while Tanner stage II refers to the first stages of puberty, progressing to final adult development as Tanner stage $\mathrm{V}(3,4)$.

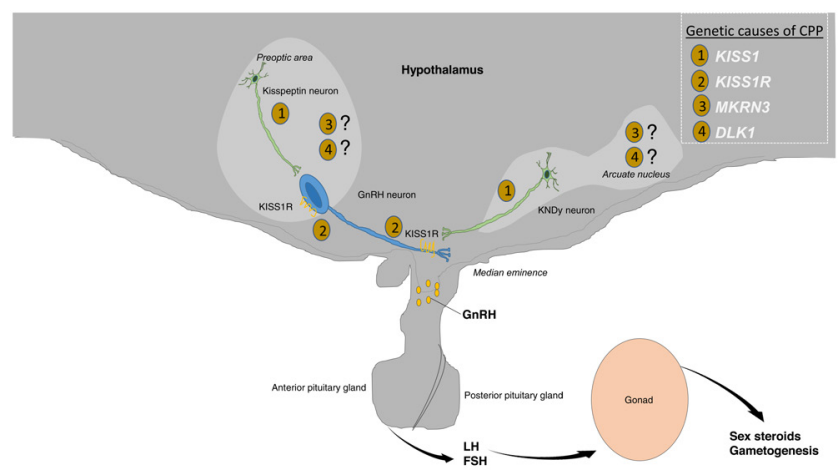

\section{Figure 1}

Activation of the hypothalamic-pituitary-gonadal axis during pubertal onset. The hallmark of pubertal onset is pulsatile hypothalamic gonadotropin-releasing hormone $(\mathrm{GnRH})$ release, likely due to increases in activators such as kisspeptin, the most potent known stimulator of GnRH secretion, produced by kisspeptin neurons in the preoptic area and in the arcuate nucleus (where they co-secrete neurokinin B and dynorphin and are hence known as KNDy neurons). Kisspeptin signals directly via kisspeptin receptors (KISS1R) on GnRH neurons to control pulsatile $\mathrm{GnRH}$ release, which in turn leads to release of luteinizing hormone $(\mathrm{LH})$ and follicle-stimulating hormone (FSH) from the pituitary, with subsequent downstream activation of sex steroid production testosterone from the testes and estrogen and progesterone from the ovaries - and gametogenesis. Genetic variants in CPP include mutations in (1) KISS1 and (2) KISS1R, affecting kisspeptin and its receptor, respectively, as well as in (3) MKRN3 and (4) DLK1, for which the mechanisms of action in the hypothalamus are still being fully elucidated.

\section{Normal pubertal timing}

Girls typically enter puberty between ages 8 and 13 years, while boys typically enter puberty between 9 and 14 years $(4,5)$. Sex differences are present in the timing of pubertal onset, as girls enter puberty approximately 1 to 2 years earlier than boys. Interestingly, there are also sex differences in the pathologic variants of pubertal timing as girls are at increased risk for early puberty, while boys are increased risk for delayed puberty, yet the mechanisms leading to these differences are unknown (6). The onset of central precocious puberty should be confirmed by an experienced clinician, as isolated thelarche or adrenarche can sometimes be confused for the onset of central puberty (7). The appearance of adult body odor, axillary hair and pubic hair may be due to normal age-related activation of the adrenal gland during adrenarche. This typically occurs 
at the same time as central puberty, but can sometimes occur earlier and is not synonymous with the onset of central puberty (7).

Definitions of normal pubertal timing in girls, including progression of secondary sexual characteristics and pubertal growth spurt, are based on hallmark studies performed by Marshall and Tanner in the late 1960s (4). In the cohort of 192 British girls who were followed, mean Tanner stage II breast development occurred at age 11.5 years (range 8.5-13 years), pubic hair development at 11.69 years, and menarche at 13.47 years (4). However, subsequent studies by Tanner supported the onset of breast development at age 10.0 years and mean age of menarche at 12.9 years ( 8 ).

In the United States and Europe, the decline in mean age of menarche with industrialization has essentially plateaued since the 1960s, with further minor declines in the mean age of menarche by $2.5-4$ months over the past 25 years, but with a far greater decline observed in age of onset of breast development (9). The Pediatric Research in Office Setting (PROS) performed in the 1990s was the largest study to date, with more than 17,000 participants, evaluated by 65 pediatricians across the United States (10). The authors concluded that, on average, Caucasian girls entered puberty by age 10, approximately 1 year earlier than previously reported, and African-American girls entered puberty between the ages of 8 and 9 years, approximately 2 years earlier than previously reported (10).

Based on the PROS study, the Lawson Wilkins Pediatric Endocrine Society published guidelines suggesting that the definition of precocious, or abnormally early, puberty as the onset before age 8 years in females was 'outdated' (11). It sparked controversy with its recommendation precocious puberty should be defined as breast development prior to age 7 years in Caucasian girls and prior to age 6 years in African-American girls (11). These guidelines suggested an allowance for more flexibility in the extent of evaluation, including whether brain magnetic resonance imaging is necessary, and in the management of affected children between the ages of 6 and 8 years in girls (11).

The guidelines suggested unchanged consideration for evaluation of precocious puberty in boys. Marshall and Tanner in 1970 had suggested pubertal onset after age 9.5 years was normal (5). However, as in girls, the PROS study suggested the onset of puberty was also occurring earlier than previously reported in boys, at a mean age of 10.14 years in Caucasian boys and 9.14 years in
African-American boys (12), further supporting ethnic differences in the age of pubertal onset.

These clinical guidelines also raised international awareness about secular trends in pubertal timing and whether the revised age-based definitions were warranted. More recent evaluations in the Copenhagen Puberty Study found earlier age of onset of breast development and slight advancement in age of menarche from children evaluated in the mid-2000s (13). While minor advances in the age of menarche have been observed in the United States and Europe since the 1960s, more dramatic reductions have been observed in countries with improving socioeconomic status such as Indonesia, Brazil, Argentina and China, often in the setting of increased rates of childhood obesity $(14,15,16,17,18,19,20)$. Furthermore, increasing recognition of environmental factors and exposures have been described in association with an earlier age of puberty, such as the effects of maternal smoking during pregnancy, of girls being raised without a father, and of some endocrine-disrupting chemicals $(21,22,23)$.

\section{Central precocious puberty}

Precocious puberty is traditionally defined as the onset of breast development before the age of 8 years in girls and testicular enlargement $\geq 4 \mathrm{~mL}$ before the age of 9 years in boys (24). Differentiation of precocious puberty from benign variants, such as premature thelarche or premature adrenarche, should be made by an experienced clinician (7). The underlying pathophysiology may be central (GnRH-dependent) or peripheral (GnRH-independent). Central precocious puberty (CPP) is due to premature activation of GnRH secretion. CPP disproportionately affects girls compared to boys; the mechanisms leading to these differences are unknown (24). Understanding more common causes of CPP, including genetic etiologies, is vital given that CPP has important short- and longterm implications for women, including increased risk of psychosocial distress, short stature, obesity, cardiovascular disease and type 2 diabetes in adulthood (25).

The gold standard to establish a biochemical diagnosis is an assessment of gonadotropins, predominantly $\mathrm{LH}$, after administration with exogenous $\mathrm{GnRH}$ or $\mathrm{GnRH}$ agonists (24). However, basal LH levels are also being utilized in some settings, as improved laboratory methods for LH assays have become available $(24,26)$. In contrast to serum estradiol levels in girls, which are typically not helpful, in boys, serum testosterone levels are an 
excellent marker of precocious puberty, although do not differentiate between central or peripheral etiologies (24). Commonly used imaging studies include bone age $\mathrm{X}$-rays, which typically demonstrate a skeletal age that is advanced by 2 years or more from chronologic age (24). Pelvic ultrasonography can indicate uterine exposure to estradiol and help identify an etiology of peripheral precocious puberty, but it is not a part of the diagnostic criteria for precocious puberty $(24,26)$. Brain MRI is an important part of the diagnostic evaluation in order to exclude a hypothalamic hamartoma or other organic abnormalities, especially before the CPP is classified as 'idiopathic' $(24,26)$.

In girls, CPP is most commonly deemed idiopathic, for which no identifiable cause is identified (24). However, emerging genetic causes of CPP, especially mutations in Makorin Ring Finger Protein 3 (MKRN3) are increasingly being identified in cases previously deemed idiopathic $(27,28,29,30,31,32,33,34,35,36,37,38,39,40,41,42$, $43,44,45,46,47,48,49,50)$. While CPP less commonly affects boys, when it does occur, it is more likely to have an identifiable pathologic cause, such as a hypothalamic hamartoma (24). Given its increasing significance, the focus of the remainder of this review will be on the recently identified genetic causes of CPP.

\section{Support for a genetic basis in pubertal timing}

The timing of pubertal onset is influenced by a complex interaction of genetic, nutritional, environmental, and epigenetic factors (51). The genetic contribution to pubertal timing is supported by the strong correlation between the ages that children and their parents begin puberty. Twin studies also support a genetic component, demonstrating a higher concordance of the timing of development of secondary sexual characteristics, including menarche in girls, in monozygotic compared to dizygotic twins $(52,53,54,55)$.

While variants in more than 50 genes have been described in association with hypogonadotropic hypogonadism, which often presents with delayed puberty, until recently, genetic variants had not been a major identified etiology of CPP $(24,56)$. To date, mutations in four genes (KISS1, KISS1R, MKRN3, DLK1) have been described as causal variants leading to CPP, with loss-of-function mutations in MKRN3 as the most common genetic etiology identified to date $(28,57)$.

\section{Known genetic variants described in association with CPP}

\section{KISS1R}

The first identified monogenic cause of CPP, described in 2008, was an activating mutation in G Protein Coupled Receptor 54 (GPR54), now more commonly referred to as KISS1R, encoding a receptor that binds its ligand, kisspeptin (Fig. 1) (58). Loss-of-function mutations in KISS1R had been described previously in association with hypogonadotropic hypogonadism (59). A gain-offunction mutation in KISS1R, a substitution of proline for arginine at codon 386, was reported in a girl with CPP. Inheritance could not be assessed as she was adopted. Breast development was reported since birth with a progression such that by age 8 years, she had Tanner stage IV breasts and advanced skeletal age of 11 years.

In vitro studies suggested that this mutation prolongs intracellular KISS1R signaling in response to kisspeptin $(58,60)$. In contrast to other gain-of-function mutations in $G$ protein-coupled receptors, which typically result in constitutive activation of the receptor, the reported gainof-function mutation in KISS1R did not result in a change in receptor activity under basal conditions or in affinity for the kisspeptin ligand. Rather, data in cellular models support a mechanism involving nonconstitutive receptor activation, in which there is a reduction of the rate of degradation of the kisspeptin receptor, and internalized mutant receptors are recycled back to the plasma membrane rather than being degraded $(58,60)$.

\section{KISS1}

Subsequently, a heterozygous missense mutation (p.P74S) in the ligand, kisspeptin, encoded by the gene KISS1, was described in a 1-year-old boy and was associated with higher resistance to degradation (61). A second missense mutation in KISS1 was also reported in two girls affected with CPP at age 5.5-6 years; however, it was concluded to be a rare single nucleotide polymorphism, at least in the heterozygous state. Other polymorphisms in KISS1 have been reported but were not found to lead to amino acid changes and therefore were not thought to be causal variants (62). Other investigators have screened cohorts of children with CPP for activating mutations in KISS1 and KISS1R but have not identified mutations, suggesting that these appear to be rare causes of CPP $(63,64,65)$. 


\section{MKRN3}

Makorin Ring Finger Protein 3 (MKRN3), located within the Prader-Willi syndrome (PWS) region on chromosome 15q11.2 (Fig. 2A), was reported in 2013 as the first gene in which loss-of-function mutations were associated with CPP, with variants initially identified by exome sequencing in five families (27). Multiple novel variants, including frameshift, nonsense, and missense mutations, in MKRN3 across various families, ethnicities and geographical regions have now been reported $(27,28$, $29,30,31,32,33,34,35,36,37,38,39,40,41,42,43$, $44,45,46,47,48,49,50)$. Mutations in MKRN3 are now the most common known genetic etiology of CPP and are more common in familial CPP (33-46\% of cases) compared to sporadic CPP (3.9\% of cases) (28). Affected individuals with CPP due to MKRN3 mutations have a median age of puberty onset of 6.0 years in girls (ranging from 3.0 to 7.5 years) and 8.25 years in boys (ranging from 5.9 to 9.0 years); the earlier onset of puberty in girls suggests that girls may be more severely affected by mutations in MKRN3 than boys. However, based on the pooled analysis of cases of familial CPP, boys with CPP appear to be more likely to harbor a mutation in MKRN3 than girls with CPP (28).
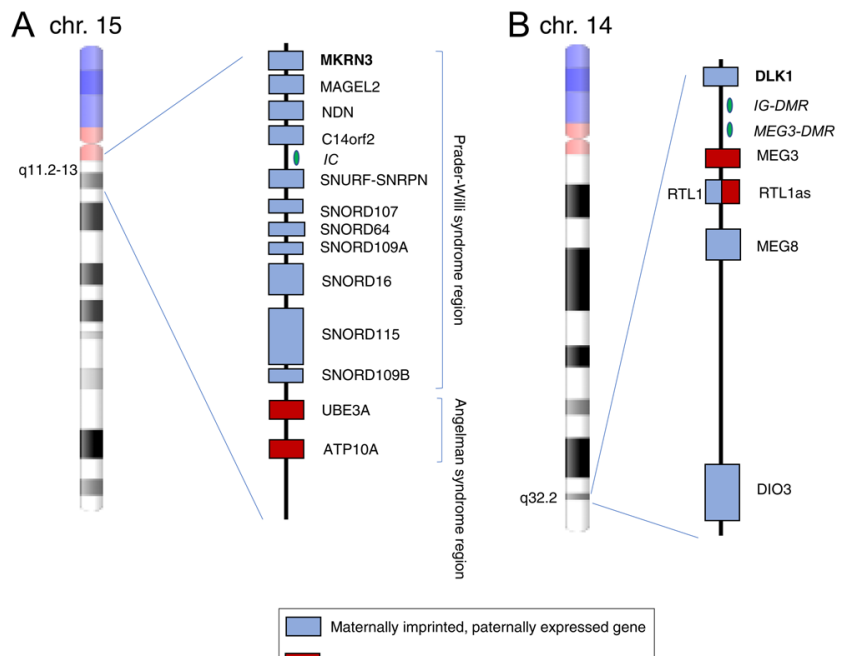

Paternally imprinted, maternally expresced gene

\section{Figure 2}

(A) Imprinted genes in the Prader-Willi syndrome and Angelman syndrome regions of chromosome 15q11.2-13. (B) Temple syndrome region of chromosome 14q32.2. Not drawn to scale. Maternally imprinted, paternally expressed genes are indicated in blue boxes and paternally imprinted, maternally expressed genes in red boxes. IC, imprinting center; DMR, differentially methylated regions. Adapted from $(69,102)$.
$M K R N 3$ is maternally imprinted or silenced; therefore, only the paternal allele is expressed and the MKRN3 protein is expressed in a parent-of-origin specific pattern (66) (Figs 2A and 3). Like other genes in the Prader-Willi locus, MKRN3 is within a conserved cluster, common for imprinted genes, under the control of a bipartite imprinting center, the PWS-IC and AS-IC (Fig. 2A) (67). PWS results from a loss of a cluster of genes normally expressed from the paternal allele, while conversely, Angelman syndrome results from loss of genes normally expressed from the maternal allele. PWS is characterized by hypotonia, paradoxical early failure to thrive, followed by childhood hyperphagia and obesity, developmental delay, and multiple endocrinopathies including hypogonadism (68). However, CPP has been reported in up to $3.5 \%$ of patients with PWS and may be underreported (68). Loss of the paternally inherited genes in the PWS typically occurs via deletion but can also occur by uniparental disomy or epimutations and microdeletions in the imprinting center (69). These mechanisms could also lead to alterations in MKRN3 expression, leading to CPP, but have not yet been reported.

MKRN3, a member of the makorin family, is a zinc finger protein with a characteristic RING (C3HC4) zinc
A

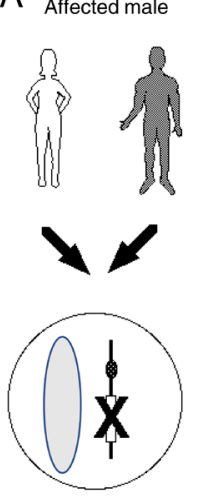

Normal allele imprinted Mutant allele expressed Clinical phenotype present
B

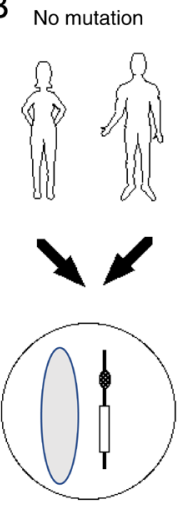

Normal allele imprinted Normal allele expressed No clinical phenotype

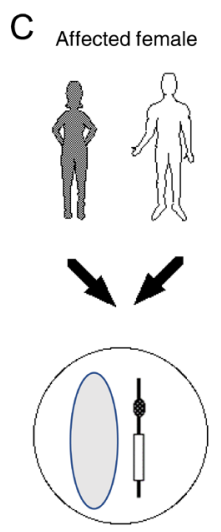

Mutant allele imprinted Normal allele expressed No clinical phenotype

\section{Figure 3}

Imprinting pattern of maternally imprinted, paternally expressed genes MKRN3 and DLK1. (A) Maternal allele is imprinted or silenced; mutant paternal allele is expressed, resulting in phenotype of central precocious puberty. (B) Maternal allele is normally imprinted and normal paternal allele is expressed, resulting in normal puberty. (C) Maternal allele containing mutation is imprinted; normal paternal allele is expressed, resulting in no pathologic phenotype (i.e. normal puberty). Adapted from (103). 
finger motif found in most E3 ubiquitin ligases, as well as an array of $\mathrm{C} 3 \mathrm{H}$ domains found in ribonucleoproteins (66). The actions of E3 ubiquitin ligases include mediating the transfer of ubiquitin from an E2 ubiquitin-conjugating enzyme to target protein substrates, which can target the protein substrates for degradation (70). MKRN3 may have multiple protein targets, suggested by a proteinprotein interaction study performed in MKRN3 knockout human pluripotent stem cell lines differentiated into GNRH1-expressing neurons, which identified 81 interacting proteins, including some involved in pubertal timing, insulin signaling, RNA metabolism and cellcell adhesion (71). Additionally, Mkrn3 was reported to bind to neuronal pentraxin-1 (Nptx1), a secreted protein important in neuronal development and highly expressed in the mouse hypothalamus during pubertal onset (72). Through interaction with an E3 ubiquitin ligase domain in Mkrn3, Nptx1 may be polyubiquitinated by Mkrn3 for degradation (72).

In mice, expression of Mkrn3 is high in the hypothalamus in the neonatal and juvenile periods and declines abruptly prior to pubertal onset, supporting its role as an inhibitor of the pathways leading to puberty initiation, and it is hypothesized to act upstream or at the level of kisspeptin and/or GnRH neurons (27). Its inhibitory role is further supported by reports of declining serum MKRN3 levels in girls and boys before pubertal onset $(73,74,75)$. Serum levels of MKRN3 have also been shown to be lower in girls with CPP compared to agematched controls and comparable to children matched for pubertal stage $(76,77)$. It would be of interest to validate the MKRN3 assay used in patients expected to have negligible MKRN3 protein synthesis, such as those with frameshift or nonsense mutations, or patients with Prader-Willi syndrome $(27,29)$.

\section{DLK1}

More recently, a mutation in Delta-like noncanonical Notch ligand 1 (DLK1), located on chromosome 14q32.2, was reported as a novel genetic cause of CPP (78) (Fig. 2B). Like MKRN3, DLK1 is a maternally imprinted, paternally expressed gene (Fig. 3). A family involving four affected sisters was described with the onset of breast development between the ages of 4.6 and 5.9 years, with biochemically confirmed CPP. The paternal grandmother also had a history of premature menarche, suggesting that she may have also been affected. A complex genetic defect detected by genomic sequencing in DLK1, involving a $\sim 14 \mathrm{~kb}$ deletion, encompassing the entirety of exon
1, including the translational start site, and a 269-bp duplication of intron 3 was identified (78). Subsequently, three frameshift mutations of DLK1 were reported in five women from three families with CPP (79). Serum DLK1 concentrations were undetectable in all patients with reported loss-of-function DLK1 mutations $(78,79)$. Interestingly, a metabolic phenotype including increased rates of obesity, early onset glucose intolerance, type 2 diabetes mellitus, and hyperlipidemia were found to be more prevalent in the patients with DLK1 mutations compared to patients with CPP not identified to have DLK1 mutations. Additionally, two affected sisters also exhibited polycystic ovary syndrome and infertility (79). The emerging clinical phenotype suggests that DLK1 may represent a novel link between reproduction and metabolism.

DLK1, also known as Preadipocyte factor 1 (Pref-1) or Fetal antigen 1 (FA1), encodes an EGF-like membranebound protein, is likely involved in the Notch signaling pathway, and is a modulator of adipogenesis (80). The DLK1 imprinting pattern is under the control of two differentially methylated regions (DMRs), the intergenic differentially methylated region (IG-DMR) and the postfertilization-derived secondary MEG3-DMR (Fig. 2B) (81). Loss of DLK1 in conjunction with two other genes from the paternally inherited chromosome, RTL1 and DIO3, leads to Temple syndrome (82). Mechanistically, the loss of the paternal alleles is typically acquired through maternal uniparental disomy, deletion, or less commonly epigenetic loss of methylation or deletion of the DMRs (83). Temple syndrome is characterized by pre- and post-natal growth retardation, hypotonia, motor delay, and small hands. Conversely, loss of the maternally inherited alleles, Maternally Expressed 3 (MEG3), Maternally Expressed 8 (MEG8) and Retrotransposon Like 1 antisense (RTL1as), leads to Kagami syndrome, which is characterized by dysmorphic facies, bell-shaped thorax with coat-hanger appearance of the ribs, abdominal wall defects, pulmonary hypoplasia and intellectual disability (69). Interestingly, CPP is described in $86 \%$ of affected individuals in Temple syndrome, with a mean age of menarche at age 10 years and 2 months, which may contribute to the syndrome's phenotype of short stature in adulthood (82).

The causative gene of this reproductive phenotype in Temple syndrome was not previously identified. However, the role of $D L K 1$ in pubertal timing had been implicated by a genome-wide association study (GWAS) showing that single nucleotide polymorphisms (SNPs) near the paternally inherited $D L K 1$ were associated with earlier age of menarche (84). Subsequently, monogenic mutations 
in DLK1 in association with CPP were reported (78, 79). Interestingly, this is in contrast to loss-of-function mutations in $M K R N 3$, which were first described in association with CPP and subsequently SNPs near MKRN3 were identified by GWAS in association with earlier age of menarche $(27,84)$.

Polymorphisms in other candidate genes such as LIN28B and the paternally imprinted gene KCNK9 have also been described in association with the age of menarche and remain candidates as monogenic causes of CPP (84). Lin28 Homolog B (LIN28B), located on chromosome 6, a post-transcriptional repressor of microRNAs of the LET7 family, has been implicated in pubertal timing by genomewide association studies in which a genomic sequence variant near $L I N 28 B$ was strongly associated with earlier age of menarche and short stature $(84,85)$. Patients with CPP have been screened for causative variants in $L I N 28 B$, but none have been identified to date (86).

\section{Role of imprinted genes in puberty}

Two of the four described monogenic causes of CPP are imprinted genes, raising the possibility that imprinting plays an important role in the regulation of puberty and that other imprinted genes might also be involved in pubertal timing (87). There are several hundred genes predicted to be imprinted in the human genome and approximately 50 human imprinted genes have been described to date (88). Genomic imprinting allows a gene to be expressed in a parent-of-origin specific manner through epigenetic modification which silences, or imprints, one allele without modifying the DNA sequence (88). Thus, in contrast to most autosomal genes which have biallelic expression, imprinted genes typically exhibit monoallelic, or mostly monoallelic, expression (Fig. 3). Well-known epigenetic modifications include changes in methylation of DNA CpG (cytosine-guanine) dinucleotides or histone protein modifications (89). However, gene expression can also vary based on tissuespecific and developmental-specific patterns of epigenetic modifications as well as environmental influences.

Imprinted genes are important in growth and development, as evident by alterations in growth observed in disorders such as Beckwith-Wiedemann and Russell-Silver syndromes (90). The kinship, or parental conflict, theory proposes that imprinting may have evolved because of competition between the maternal and paternal genomes, resulting in maternal alleles that are silenced for genes that may increase demands on the mother $(88,91,92,93)$. This theory posits that the gene silencing ensures the mother's survival, allows equal distribution of nutrients among offspring, and that the most important relationship is the interaction between child and mother (94). Models of imprinting disorders in rodents and humans suggest that paternally expressed genes tend to promote growth while maternally expressed genes tend to restrict growth (95). The correlation of paternally inherited variants in MKRN3 and DLK1 in GWAS studies, as well as monogenetic mutations in these genes in CPP, has been proposed to be due to differential effects from the mother vs father in terms of the influence of timing of sexual maturation and its contribution to overall fitness (87).

Epigenetic modifications have an increasingly recognized role in pubertal timing (51). Methylome profiling of girls with precocious and normally timed pubertal onset before and after puberty revealed a widespread pattern of differential DNA hypermethylation. The majority of differentially methylated regions were hypermethylated in the post-pubertal group, compared to the prepubertal group, suggesting that pubertal onset is associated with specific changes in the regulatory control of epigenetic modification (96).

\section{Treatment}

The mainstay of treatment for CPP is $\mathrm{GnRH}$ agonist therapy, which is typically administered by intramuscular injection or a subcutaneous implant (97). The capacity of endogenous GnRH to stimulate LH synthesis and release can be interrupted by continuous delivery of a GnRH agonist, leading to desensitization and downregulation of GnRH signaling $(98,99)$. Downstream effects include decreased release of pituitary gonadotropins and, subsequently, decreased release of gonadal sex steroids. Use of GnRH antagonists has potential therapeutic application. However, use has been limited by availability, modes of administration, cost and lack of approved indication. Newer kisspeptin and neurokinin B antagonists are also being developed and may be alternative therapeutic options in the future $(100,101)$.

\section{Perspectives}

The more recent recognition of MKRN3 and DLK1 as important influences in pubertal timing allows for opportunities for innovation in the diagnosis and 
treatment of CPP and for an increased likelihood of identifying the etiology of 'idiopathic' CPP. GnRH agonist stimulation tests are the current gold standard for the diagnosis of CPP but are time consuming, invasive and expensive. Biochemical measurement of serum levels of MKRN3 or DLK1 proteins could be innovative, less laborintensive diagnostic tools for earlier detection of CPP (24). Additionally, assessment of serum levels of MKRN3 and DLK1 may serve as a way to identify unrecognized mutations in these genes, prompting genetic analysis which is not currently standard in clinical practice (76, 77, 78, 79). The manipulation of MKRN3 and DLK1 activity also has therapeutic implications, as antagonizing these proteins or their respective targets could offer new strategies for the treatment of CPP.

\section{Conclusion}

In contrast to the many genetic causes identified in hypogonadotropic hypogonadism, to date, only four monogenetic causes of CPP have been identified, including mutations in KISS1, KISS1R, MKRN3 and DLK1 (28, 58, 61, $77,78)$. CPP that was previously classified as 'idiopathic' is increasingly being explained by the identification of genetic variants, especially in MKRN3 $(78,79)$. Eliciting a detailed family history of pubertal timing is important as this may raise suspicion for genetic etiologies and should be interpreted within the context of a possible imprinting inheritance pattern $(24,28)$. Novel genetic variants are likely to continue to be identified and reported, and consideration of imprinted genes, which appear to have an important role in the control of puberty, should continue to be explored $(78,87)$. Presently, this is an exciting time for the field, as new genes involved in precocious puberty are identified, ultimately these discoveries advance our understanding of the fundamental biology of pubertal onset and provide opportunities for innovation in the diagnosis and treatment of pubertal disorders.

\section{Declaration of interest}

The authors declare that there is no conflict of interest that could be perceived as prejudicing the impartiality of this review.

\section{Funding}

This work was supported by the National Institutes of Health 5K12HD051959 and Loan Repayment Program, Pediatric Endocrine Society Clinical Scholar Award and Boston Children's Office of Faculty Development Award supporting Dr Roberts and by National Institutes of Health R01HD082314 awarded to Dr Kaiser.

\section{Acknowledgement}

The authors would like to thank Soukayna Chouman for her assistance with the figures.

\section{References}

1 Palmert MR \& Boepple PA. Variation in the timing of puberty: clinical spectrum and genetic investigation. Journal of Clinical Endocrinology and Metabolism 200186 2364-2368. (https://doi. org/10.1210/jcem.86.6.7603)

2 Fergani C \& Navarro VM. Expanding the role of tachykinins in the neuroendocrine control of reproduction. Reproduction 2016153 R1-R14. (https://doi.org/10.1530/REP-16-0378)

3 Wheeler MD. Physical changes of puberty. Endocrinology and Metabolism Clinics of North America 199120 1-14. (https://doi. org/10.1016/S0889-8529(18)30279-2)

4 Marshall WA \& Tanner JM. Variations in pattern of pubertal changes in girls. Archives of Disease in Childhood 196944 291-303. (https:// doi.org/10.1136/adc.44.235.291)

5 Marshall WA \& Tanner JM. Variations in the pattern of pubertal changes in boys. Archives of Disease in Childhood 1970 45 13-23. (https://doi.org/10.1136/adc.45.239.13)

6 Bianco SD. A potential mechanism for the sexual dimorphism in the onset of puberty and incidence of idiopathic central precocious puberty in children: sex-specific kisspeptin as an integrator of puberty signals. Frontiers in Endocrinology 20123 149. (https://doi. org/10.3389/fendo.2012.00149)

7 Kaplowitz P, Bloch C \& Section on Endocrinology, American Academy of Pediatrics. Evaluation and referral of children with signs of early puberty. Pediatrics 2016137 e20153732. (https://doi. org/10.1542/peds.2015-3732)

8 Tanner JM \& Davies PS. Clinical longitudinal standards for height and height velocity for North American children. Journal of Pediatrics 1985107 317-329. (https://doi.org/10.1016/s00223476(85)80501-1)

9 Parent AS, Teilmann G, Juul A, Skakkebaek NE, Toppari J \& Bourguignon JP. The timing of normal puberty and the age limits of sexual precocity: variations around the world, secular trends and changes after migration. Endocrine Reviews 200324 668-693. (https:// doi.org/10.1210/er.2002-0019)

10 Herman-Giddens ME, Slora EJ, Wasserman RC, Bourdony CJ, Bhapkar MV, Koch GG \& Hasemeier CM. Secondary sexual characteristics and menses in young girls seen in office practice: a study from the Pediatric Research in Office Settings network. Pediatrics 199799 505-512. (https://doi.org/10.1542/peds.99.4.505)

11 Kaplowitz PB \& Oberfield SE. Reexamination of the age limit for defining when puberty is precocious in girls in the United States: implications for evaluation and treatment. Drug and Therapeutics and Executive Committees of the Lawson Wilkins Pediatric Endocrine Society. Pediatrics 1999104 936-941. (https://doi. org/10.1542/peds.104.4.936)

12 Herman-Giddens ME, Steffes J, Harris D, Slora E, Hussey M, Dowshen SA, Wasserman R, Serwint JR, Smitherman L \& Reiter EO. Secondary sexual characteristics in boys: data from the Pediatric Research in Office Settings Network. Pediatrics 2012130 e1058-e1068. (https://doi.org/10.1542/peds.2011-3291)

13 Asglaede L, Sorensen K, Petersen JH, Skakkebaek NE \& Juul A. Recent decline in age of breast development: the Copenhagen Puberty Study. Pediatrics 2009123 e932-e939. (https://doi.org/10.1542/ peds.2008-2491)

14 Brix N, Ernst A, Lauridsen LLB, Parner E, Stovring H, Olsen J, Henriksen TB \& Ramlau-Hansen $\mathrm{CH}$. Timing of puberty in boys and girls: a population based study. Paediatric and Perinatal Epidemiology 201933 70-78. (https://doi.org/10.1111/ppe.12507) 
15 Papadimitriou A, Pantsiotou S, Douros K, Papadimitriou DT, Nicolaidou P \& Fretzayas A. Timing of pubertal onset in girls: evidence for non-Gaussian distribution. Journal of Clinical Endocrinology and Metabolism 200893 4422-4425. (https://doi. org/10.1210/jc.2008-0661)

16 Semiz S, Kurt F, Kurt DT, Zencir M \& Sevinc O. Pubertal development of Turkish children. Journal of Pediatric Endocrinology and Metabolism 200821 951-961. (https://doi.org/10.1515/ jpem.2008.21.10.951)

17 Wahab A, Wilopo SA, Hakimi M \& Ismail D. Declining age of menarche in Indonesia: a systematic review and meta-analysis. International Journal of Adolescent Medicine and Health 2018 In press. (https://doi.org/10.1515/ijamh-2018-0021)

18 Feibelmann TC, Silva AP, Resende DC, Resende EA, Scatena LM \& Borges Mde F. Puberty in a sample of Brazilian schoolgirls: timing and anthropometric characteristics. Archives of Endocrinology and Metabolism 201559 105-111. (https://doi.org/10.1590/23593997000000021)

19 Chen FF, Wang YF \& Mi J. Timing and secular trend of pubertal development in Beijing girls. World Journal of Pediatrics $2014 \mathbf{1 0}$ 74-79. (https://doi.org/10.1007/s12519-014-0456-2)

20 Martin MA \& Valeggia C. Timing of pubertal growth and menarche in indigenous Qom girls of Argentina. Annals of Human Biology 2018 45 321-329. (https://doi.org/10.1080/03014460.2018.1486455)

21 Brix N, Ernst A, Lauridsen LLB, Parner ET, Olsen J, Henriksen TB \& Ramlau-Hansen $\mathrm{CH}$. Maternal smoking during pregnancy and timing of puberty in sons and daughters: a population-based cohort study. American Journal of Epidemiology 2019188 47-56. (https://doi. org/10.1093/aje/kwy206)

22 Gaydosh L, Belsky DW, Domingue BW, Boardman JD \& Harris KM. Father absence and accelerated reproductive development in nonHispanic white women in the United States. Demography 201855 1245-1267. (https://doi.org/10.1007/s13524-018-0696-1)

23 Wolff MS, Pajak A, Pinney SM, Windham GC, Galvez M, Rybak M, Silva MJ, Ye X, Calafat AM, Kushi LH et al. Association of urinary phthalate and phenol biomarkers with menarche in a multiethnic cohort of young girls. Reproductive Toxicology 201767 56-64. (https:// doi.org/10.1016/j.reprotox.2016.11.009)

24 Latronico AC, Brito VN \& Carel JC. Causes, diagnosis and treatment of central precocious puberty. Lancet. Diabetes and Endocrinology 2016 4 265-274. (https://doi.org/10.1016/S2213-8587(15)00380-0)

25 Yoo JH. Effects of early menarche on physical and psychosocial health problems in adolescent girls and adult women. Korean Journal of Pediatrics 201659 355-361. (https://doi.org/10.3345/ kjp.2016.59.9.355)

26 Bangalore Krishna K, Fuqua JS, Rogol AD, Klein KO, Popovic J, Houk CP, Charmandari E, Lee PA, Freire AV, Ropelato MG et al. Use of gonadotropin-releasing hormone analogs in children: update by an international consortium. Hormone Research in Paediatrics 201991 357-372. (https://doi.org/10.1159/000501336)

27 Abreu AP, Dauber A, Macedo DB, Noel SD, Brito VN, Gill JC, Cukier P, Thompson IR, Navarro VM, Gagliardi PC et al. Central precocious puberty causes by mutations in the imprinted gene MKRN3. New England Journal of Medicine 2013368 2467-2475. (https://doi. org/10.1056/NEJMoa1302160)

28 Valadares LP, Meireles CG, De Toledo IP, Santarem de Oliveira R, Goncalves de Castro LC, Abreu AP, Carroll RS, Latronico AC, Kaiser UB, Guerra ENS et al. MKRN3 mutations in central precocious puberty: a systematic review and meta-analysis. Journal of the Endocrine Society 20193 979-995. (https://doi.org/10.1210/js.201900041)

29 Aycan Z, Savaş-Erdeve Ş, Çetinkaya S, Kurnaz E, Keskin M, Şahin NM, Bayramoğlu E \& Ceylaner G. Investigation of MKRN3 mutation in patients with familial central precocious puberty. Journal of Clinical Research in Pediatric Endocrinology 201810 223-229. (https://doi. org/10.4274/jcrpe.5506)
30 Bessa DS, Macedo DB, Brito VN, França MM, Montenegro LR, CunhaSilva M, Silveira LG, Hummel T, Bergadá I, Braslavsky D et al. High frequency of MKRN3 mutations in male central precocious puberty previously classified as idiopathic. Neuroendocrinology 2017105 17-25. (https://doi.org/10.1159/000446963)

31 Fanis P, Skordis N, Toumba M, Papaioannou N, Makris A, Kyriakou A, Neocleous V \& Phylactou LA. Central precocious puberty cause by novel mutations in the promoter and 5'-UTR region of the imprinted MKRN3 gene. Frontiers in Endocrinology 201910 1-10. (https://doi. org/10.3389/fendo.2019.00677)

32 Christoforidis A, Skordis N, Fanis P, Dimitriadou M, Sevastidou M, Phelan MM, Neocleous V \& Phylactou LA. A novel MKRN3 nonsense mutation causing familial central precocious puberty. Endocrine 2017 56 446-449. (https://doi.org/10.1007/s12020-017-1232-6)

33 Dimitrova-Mladenova MS, Stefanova EM, Glushkova M, Todorova AP, Todorov T, Konstantinova MM, Kazakova K \& Tincheva RS. Males with paternally inherited MKRN3 mutations may be asymptomatic. Journal of Pediatrics 2016179 263-265. (https:// doi.org/10.1016/j.jpeds.2016.08.065)

34 Grandone A, Cantelmi G, Cirillo G, Marzuillo P, Luongo C, Giudice EMD \& Perrone L. A case of familial central precocious puberty caused by a novel mutation in the Makorin RING Finger Protein 3 gene. BMC Endocrine Disorders 201515 60. (https://doi. org/10.1186/s12902-015-0056-8)

35 Jeong HR, Lee HS \& Hwang JS. Makorin Ring Finger 3 gene analysis in Koreans with familial precocious puberty. Journal of Pediatric Endocrinology and Metabolism 201730 1197-1201. (https://doi. org/10.1515/jpem-2016-0471)

36 Känsäkoski J, Raivio T, Juul A \& Tommiska J. A missense mutation in MKRN3 in a Danish girl with central precocious puberty and her brother with early puberty. Pediatric Research 201578 709-711. (https://doi.org/10.1038/pr.2015.159)

37 Lee H, Jin H-S, Shim Y, Jeong H, Kwon E, Choi V, Kim M-C, Chung I-S, Jeong S-Y \& Hwang J. Low frequency of MKRN3 mutations in central precocious puberty among Korean girls. Hormone and Metabolic Research 201548 118-122. (https://doi. org/10.1055/s-0035-1548938)

38 Lin WD, Wang CH \& Tsai FJ. Genetic screening of the Makorin Ring Finger 3 gene in girls with idiopathic central precocious puberty. Clinical Chemistry and Laboratory Medicine 201654 e93-e96. (https:// doi.org/10.1515/cclm-2015-0408)

39 Macedo DB, Abreu AP, Reis ACS, Montenegro LR, Dauber A, Beneduzzi D, Cukier P, Silveira LFG, Teles MG, Carroll RS et al. Central precocious puberty that appears to be sporadic caused by paternally inherited mutations in the imprinted gene Makorin Ring Finger 3. Journal of Clinical Endocrinology and Metabolism 201499 E1097-E1103. (https://doi.org/10.1210/jc.2013-3126)

40 Macedo DB, França MM, Montenegro LR, Cunha-Silva M, Bessa DS, Abreu AP, Kaiser UB, Mendonca BB, Jorge AAL, Brito VN et al. Central precocious puberty caused by a heterozygous deletion in the MKRN3 promoter region. Neuroendocrinology 2018107 127-132. (https://doi. org/10.1159/000490059)

41 Neocleous V, Shammas C, Phelan MM, Nicolaou S, Phylactou LA \& Skordis N. In silico analysis of a novel MKRN3 missense mutation in familial central precocious puberty. Clinical Endocrinology 201684 80-84. (https://doi.org/10.1111/cen.12854)

42 Nishioka J, Shima H, Fukami M, Yatsuga S, Matsumoto T, Ushijima K, Kitamura M \& Koga Y. The first Japanese case of central precocious puberty with a novel MKRN3 mutation. Human Genome Variation 20174 17017. (https://doi.org/10.1038/hgv.2017.17)

43 Ortiz-Cabrera NV, Riveiro-Álvarez R, López-Martínez MÁ, PérezSegura P, Aragón-Gómez I, Trujillo-Tiebas MJ \& Soriano-Guillén L. Clinical exome sequencing reveals MKRN3 pathogenic variants in familial and nonfamilial idiopathic central precocious puberty. Hormone Research in Paediatrics 201787 88-94. (https://doi. org/10.1159/000453262) 
44 Schreiner F, Gohlke B, Hamm M, Korsch E \& Woelfle J. MKRN3 mutations in familial central precocious puberty. Hormone Research in Paediatrics 201482 122-126. (https://doi. org/10.1159/000362815)

45 Settas N, Dacou-Voutetakis C, Karantza M, Kanaka-Gantenbein C, Chrousos GP \& Voutetakis A. Central precocious puberty in a girl and early puberty in her brother caused by a novel mutation in the MKRN3 gene. Journal of Clinical Endocrinology and Metabolism 2014 99 E647-E651. (https://doi.org/10.1210/jc.2013-4084)

46 Simon D, Ba I, Mekhail N, Ecosse E, Paulsen A, Zenaty D, Houang M, Jesuran Perelroizen M, de Filippo GP, Salerno $\mathrm{M}$ et al. Mutations in the maternally imprinted gene MKRN3 are common in familial central precocious puberty. European Journal of Endocrinology 2016 174 1-8. (https://doi.org/10.1530/EJE-15-0488)

47 Simsek E, Demiral M, Ceylaner S \& Kirel B. Two frameshift mutations in MKRN3 in Turkish patients with familial central precocious puberty. Hormone Research in Paediatrics 201787 405-411. (https:// doi.org/10.1159/000450923)

48 Stecchini MF, Macedo DB, Reis ACS, Abreu AP, Moreira AC, Castro M, Kaiser UB, Latronico AC \& Antonini SR. Time course of central precocious puberty development caused by an MKRN3 gene mutation: a prismatic case. Hormone Research in Paediatrics 201686 126-130. (https://doi.org/10.1159/000447515)

49 Vries LD, Gat-Yablonski G, Dror N, Singer A \& Phillip M. A novel MKRN3 missense mutation causing familial precocious puberty. Human Reproduction 201429 2838-2843. (https://doi.org/10.1093/ humrep/deu256)

$50 \mathrm{Lu}$ W, Wang J, Li C, Sun M, Hu R \& Wang W. A novel mutation in 5'-UTR of Makorin Ring Finger 3 gene association with the familial precocious puberty. Acta Biochimica et Biophysica Sinica 201850 1291-1293. (https://doi.org/10.1093/abbs/gmy124)

51 Leka-Emiri S, Chrousos GP \& Kanaka-Gatenbein C. The mystery of puberty initiation: genetics and epigenetics of idiopathic central precocious puberty (ICPP). Journal of Endocrinological Investigation 201740 789-802. (https://doi.org/10.1007/s40618-017-0627-9)

52 Morris DH, Jones ME, Schoemaker MJ, Ashworth A \& Swerdlow AJ. Familial concordance for age at menarche: analyses from the Breakthrough Generations Study. Paediatric and Perinatal Epidemiology 201125 306-311. (https://doi.org/10.1111/j.13653016.2010.01183.x)

53 Van den Berg SM, Setiawan A, Bartels M, Polderman TJ, van der Vaart AW \& Boomsma DI. Individual differences in puberty onset in girls: bayesian estimation of heritabilities and genetic correlations. Behavior Genetics 200636 261-270. (https://doi.org/10.1007/s10519005-9022-y)

54 Sharma JC. The genetic contribution to pubertal growth and development studied by longitudinal growth data on twins. Annals of Human Biology 198310 163-171. (https://doi. org/10.1080/03014468300006301)

55 Treloar SA \& Martin NG. Age at menarche as a fitness trait: nonadditive genetic variance detected in a large twin sample. American Journal of Human Genetics 199047 137-148.

56 Topaloglu AK. Update on the genetics of idiopathic hypogonadotropic hypogonadism. Journal of Clinical Research in Pediatric Endocrinology 20179 113-122. (https://doi.org/10.4274/ jcrpe.2017.S010)

57 Grandone A, Capristo C, Cirillo G, Sasso M, Umano GR, Mariani M, Miraglia Del Giudice E \& Perrone L. Molecular screening of MKRN3, DLK1, and KCNK9 genes in girls with idiopathic central precocious puberty. Hormone Research in Paediatrics 201788 194-200. (https:// doi.org/10.1159/000477441)

58 Teles MG, Bianco SD, Brito VN, Trarbach EB, Kuohung W, Xu S, Seminara SB, Mendonca BB, Kaiser UB \& Latronico AC. A GPR54activating mutation in a patient with central precocious puberty. New England Journal of Medicine 2008358 709-715. (https://doi. org/10.1056/NEJMoa073443)
59 Seminara SB, Messager S, Chatzidaki EE, Thresher RR, Acierno Jr JS, Shagoury JK, Bo-Abbas Y, Kuohung W, Schwinof KM, Hendrick AG et al. The GPR54 gene as a regulator of puberty. New England Journal of Medicine 2003349 1614-1627. (https://doi.org/10.1056/ NEJMoa035322)

60 Bianco SD, Vandepas L, Correa-Medina M, Gereben B, Mukherjee A, Kuohung W, Carroll R, Teles MG, Latronico AC \& Kaiser UB. Kiss1r intracellular trafficking and degradation: effect of the Arg386Pro disease-associated mutation. Endocrinology 2011152 1616-1626. (https://doi.org/10.1210/en.2010-0903)

61 Silveira LG, Noel SD, Silveira-Neto AP, Abreu AP, Brito VN, Santos MG, Bianco SD, Kuohung W, Xu S, Gryngarten M et al. Mutations of the KISS1 gene in disorders of puberty. Journal of Clinical Endocrinology and Metabolism 201095 2276-2280. (https:// doi.org/10.1210/jc.2009-2421)

62 Ko JM, Lee HS \& Hwang JS. KISS1 gene analysis in Korean girls with central precocious puberty: a polymorphism, p.P110T, suggested to exert a protective effect. Endocrine Journal 201057 701-709. (https:// doi.org/10.1507/endocri.k10e-073)

63 Krstevska-Konstantinova M, Jovanovska J, Tasic VB, Montenegro LR, Beneduzzi D, Silveira LF \& Gucev ZS. Mutational analysis of KISS1 and KISS1R in idiopathic central precocious puberty. Journal of Pediatric Endocrinology and Metabolism 201427 199-201. (https://doi. org/10.1515/jpem-2013-0080)

64 Tommiska J, Sorensen K, Aksglaede L, Koivu R, Puhakka L, Juul A \& Raivio T. LIN28B, LIN28A, KISS1 and KISS1R in idiopathic central precocious puberty. BMC Research Notes 20114 363. (https://doi. org/10.1186/1756-0500-4-363)

65 Leka-Emiri S, Louizou E, Kambouris M, Chrousos G, De Roux N \& Kanaka-Gantenbein C. Absence of GPR54 and TACR3 mutations in sporadic cases of idiopathic central precocious puberty. Hormone Research in Paediatrics 201481 177-181. (https://doi. org/10.1159/000356913)

66 Jong MT, Carey AH, Caldwell KA, Lau MH, Handel MA, Driscoll DJ, Stewart CL, Rinchik EM \& Nicholls RD. Imprinting of a RING zinc-finger encoding gene in the mouse chromosome region homologous to the Prader-Willi syndrome genetic region. Human Molecular Genetics 19998 795-803. (https://doi.org/10.1093/ $\mathrm{hmg} / 8.5 .795)$

67 Perk J, Makedonski K, Lande L, Cedar H, Razin A \& Shemer R. The imprinting mechanism of the Prader-Willi/Angelman regional control center. EMBO Journal 200221 5807-5814. (https://doi. org/10.1093/emboj/cdf570)

68 Crinò A, Schiaffini R, Ciampalini P, Spera S, Beccaria L, Benzi F, Bosio L, Corrias A, Gargantini L, Salvatoni A et al. Hypogonadism and pubertal development in Prader-Willi syndrome. European Journal of Pediatrics 2003162 327-333. (https://doi.org/10.1007/ s00431-002-1132-4)

69 Hoffman K \& Heller R. Uniparental disomies 7 and 14. Best Practice and Research: Clinical Endocrinology and Metabolism 201125 77-100. (https://doi.org/10.1016/j.beem.2010.09.004)

70 Deshaies RJ \& Joazeiro CA. RING domain E3 ubiquitin ligases. Annual Review of Biochemistry 200978 399-434. (https://doi.org/10.1146/ annurev.biochem.78.101807.093809)

71 Yellapragada V, Liu X, Lund C, Känsäkoski J, Pulli K, Vuoristo S, Lundin K, Tuuri T, Variosalo M \& Raivio T. MKRN3 interacts with several proteins implicated in puberty timing but does not influence GNRH1 expression. Frontiers in Endocrinology 201910 48. (https:// doi.org/10.3389/fendo.2019.00048)

72 Liu H, Kong X \& Chen F. Mkrn3 functions as a novel ubiquitin E3 ligase to inhibit Nptx1 during puberty initiation. Oncotarget 20178 85102-85109. (https://doi.org/10.18632/oncotarget.19347)

73 Busch AS, Hagen CP, Almstrup K \& Juul A. Circulating MKRN3 levels decline during puberty in healthy boys. Journal of Clinical Endocrinology and Metabolism 2016101 2588-2593. (https://doi. org/10.1210/jc.2016-1488) 
74 Hagen CP, Sørensen K, Mieritz MG, Johannsen TH, Almstrup K \& Juul A. Circulating MKRN3 levels decline prior to pubertal onset and through puberty: a longitudinal study of healthy girls. Journal of Clinical Endocrinology and Metabolism 2015100 1920-1926. (https:// doi.org/10.1210/jc.2014-4462)

75 Varimo T, Dunkel L, Vaaralahti K, Miettinien PJ, Hero M \& Raivio T. Circulating makorin ring finger protein 3 levels decline in boys before the clinical onset of puberty. European Journal of Endocrinology 2016174 785-790. (https://doi.org/10.1530/EJE-15-1193)

76 Grandone A, Cirillo G, Sasso M, Capristo C, Tornese G, Marzuillo P, Luongo C, Rosaria Umano G, Festa A, Coppola R et al. MKRN3 levels in girls with central precocious puberty and correlation with sexual hormone levels: a pilot study. Endocrine 201859 203-208. (https:// doi.org/10.1007/s12020-017-1281-x)

77 Jeong HR, Lee HJ, Shim YS, Kang MJ, Yang S \& Hwang IT. Serum Makorin ring finger protein 3 values for predicting central precocious puberty in girls. Gynecological Endocrinology 201935 732-736. (https://doi.org/10.1080/09513590.2019.1576615)

78 Dauber A, Cunha-Silva M, Macedo DB, Brito VN, Abreu AP, Roberts SA, Montenegro LR, Andrew M, Kirby A, Weirauch MT et al. Paternally inherited DLK1 deletion associated with familial central precocious puberty. Journal of Clinical Endocrinology and Metabolism 2017102 1557-1567. (https://doi.org/10.1210/jc.2016-3677)

79 Gomes LG, Cunha-Silva M, Crespo RP, Ramos CO, Montengero LR, Canton A, Lees M, Spoudeas H, Dauber A, Macedo DB et al. Dlk1 is a novel link between reproduction and metabolism. Journal of Clinical Endocrinology and Metabolism 2019104 2112-2120. (https://doi. org/10.1210/jc.2018-02010)

80 Falix FA, Aronson DC, Lamers WH \& Gaemers IC. Possible roles of DLK1 in the Notch pathway during development and disease. Biochimica et Biophysica Acta 20121822 988-995. (https://doi. org/10.1016/j.bbadis.2012.02.003)

81 Kagami M, O'Sullivan MJ, Green AJ, Watabe Y, Arisaka O, Masawa N, Matsuoka K, Fukami M, Matsubara K, Kato F et al. The IG-DMR and MEG3-DMR at human chromosome 14q32.2: hierarchical interaction and distinct functional properties as imprinting control centers. PLoS Genetics 20106 e1000992. (https://doi.org/10.1371/journal. pgen.1000992)

82 Ioannides Y, Lokulo-Sodipe K, Mackay DJ, Davies JH \& Temple IK. Temple syndrome: improving the recognition of an underdiagnosed chromosome 14 imprinting disorder: an analysis of 51 published cases. Journal of Medical Genetics 201451 495-501. (https://doi. org/10.1136/jmedgenet-2014-102396)

83 Ogata T, Kagami M \& Ferguson-Smith AC. Molecular mechanisms regulating phenotypic outcome in paternal and maternal uniparental disomy for chromosome 14. Epigenetics 20083 181-187. (https://doi. org/10.4161/epi.3.4.6550)

84 Perry JR, Day F, Elks CE, Sulem P, Thompson DJ, Ferreira T, He C, Chasman DI, Esko T, Thorleifsson G et al. Parent-of-origin specific allelic associations among 106 genomic loci for age at menarche. Nature 2014514 92-97. (https://doi.org/10.1038/nature13545)

85 Ong KK, Elks CE, Li S, Zhao JH, Luan J, Andersen LB, Bingham SA, Brage S, Smith GD, Ekelund U et al. Genetic variation in LIN28B is associated with the timing of puberty. Nature Genetics $2009 \mathbf{4 1}$ 729-733. (https://doi.org/10.1038/ng.382)

86 Silveira-Neto AP, Leal LF, Emerman AB, Henderson KD, Piskounova E, Henderson BE, Gregory RI, Silveira LF, Hirschhorn JN, Nguyen TT et al. Absence of functional LIN28B mutations in a large cohort of patients with idiopathic central precocious puberty. Hormone Research in Paediatrics 201278 144-150. (https://doi.org/10.1159/000342212)

87 Kotler J \& Haig D. The tempo of human childhood: a maternal foot on the accelerator, a paternal foot on the brake. Evolutionary Anthropology 201827 80-91. (https://doi.org/10.1002/evan.21579)

88 Ishida M \& Moore GE. The role of imprinted genes in humans. Molecular Aspects of Medicine 201334 826-840. (https://doi. org/10.1016/j.mam.2012.06.009)

89 Elhamamsy AR. Role of DNA methylation in imprinting disorders: an updated review. Journal of Assisted Reproduction and Genetics 201734 549-562. (https://doi.org/10.1007/s10815-017-0895-5)

90 Jirtle RL, Sander M \& Barrett JC. Genomic imprinting and environmental disease susceptibility. Environmental Health Perspectives 2000108 271-278. (https://doi.org/10.1289/ehp.00108271)

91 Giabicani É, Brioude F, Le Bouc Y \& Netchine I. Imprinted disorders and growth. Annales d'Endocrinologie 201778 112-113. (https://doi. org/10.1016/j.ando.2017.04.010)

92 Haig D. Genomic imprinting and kinship: how good is the evidence? Annual Review of Genetics 200438 553-585. (https://doi.org/10.1146/ annurev.genet.37.110801.142741)

93 Haig D. The kinship theory of genomic imprinting. Annual Review of Ecology and Systematics 200031 9-32. (https://doi.org/10.1146/ annurev.ecolsys.31.1.9)

94 Wilkins JF \& Haig D. Parental modifiers, antisense transcripts and loss of imprinting. Proceedings. Biological Sciences 2002269 1841-1846. (https://doi.org/10.1098/rspb.2002.2096)

95 Haig D \& Wharton R. Prader-Willi syndrome and the evolution of human childhood. American Journal of Human Biology 200315 320-329. (https://doi.org/10.1002/ajhb.10150)

96 Moore T \& Reik W. Genetic conflict in early development: parental imprinting in normal and abnormal growth. Reviews of Reproduction 19961 73-77. (https://doi.org/10.1530/ror.0.0010073)

97 Bessa DS, Maschietto M, Aylwin CF, Canton APM, Brito VN, Macedo DB, Cunha-Silva M, Palhares HMC, de Resende EAMR, Borgets MF et al. Methylome profiling of healthy and central precocious puberty girls. Clinical Epigenetics 201810 146. (https:// doi.org/10.1186/s13148-018-0581-1)

98 Willemsen RH, Elleri D, Williams RM, Ong KK \& Dunger DB. Pros and cons of GnRHa treatment for early puberty in girls. Nature Reviews: Endocrinology 201410 352-363. (https://doi.org/10.1038/ nrendo.2014.40)

99 Ortmann O, Weiss JM \& Diedrich K. Gonadotropin-releasing hormone (GnRH) and GnRH agonists: mechanism of action. Reproductive Biomedicine Online 20025 (Supplement 1) 1-7. (https:// doi.org/10.1016/s1472-6483(11)60210-1)

100 Blumenfeld Z. Investigational and experimental GnRH analogs and associated neurotransmitters. Expert Opinion on Investigational Drugs 201726 661-667. (https://doi.org/10.1080/13543784.2017.1323869)

101 Newton CL, Anderson RC \& Millar RP. Therapeutic neuroendocrine agonist and antagonist analogs of hypothalamic neuropeptides as modulators of the hypothalamic-pituitary-gonadal axis. Endocrine Development 201630 106-129. (https://doi.org/10.1159/000439337)

102 Cheon CK. Genetics of Prader-Willi syndrome and Prader-Willi-Like syndrome. Annals of Pediatric Endocrinology and Metabolism 201621 126-135. (https://doi.org/10.6065/apem.2016.21.3.126)

103 McGowan R \& Martin CC. Genomic imprinting [Internet], 1998 [cited 2020]. (available at: http://people.ucalgary.ca/ browder/ imprinting.html)

Received 6 February 2020

Revised version received 23 April 2020

Accepted 3 June 2020 